https:/ / doi.org/10.18485/iipe_nsail.2020.ch6

Marko NOVAKOVIĆ ${ }^{1}$

\title{
ULOGA MEĐUNARODNIH ORGANIZACIJA U MEĐUNARODNIM ODNOSIMA - PRIMER UJEDINJENIH NACIJA
}

\begin{abstract}
Apstrakt: U pravnoj teoriji postoje brojne podele između aktera međunarodnog prava, ali jedna od posebnog značaja za ovo pitanje jeste podela na aktere sa punom i delimičnom pravnom ličnosti. Ova podela se najbolje može videti u okviru presude MSP "Reparation for Injuries" u okviru koje se eksplicitno navodi da subjekti prava u bilo kom pravnom sistemu nisu nužno identični u svojoj prirodi i u kontekstu svojih prava. Tako se države smatraju jedinim potpunim akterima, a ta potpunost se ogleda $u$ činjenici da imaju, ili barem mogu imati, sva prava i preuzeti sve obaveze $\mathrm{u}$ međunarodnopravnom sistemu. S druge strane, ostali učesnici poput međunarodnih organizacija ili pojedinca imaju samo neke elemente koji su im povereni od strane država. Međunarodne organizacije ne predstavljaju originerne subjekte međunarodnog prava - to su isključivo države. Vremenom, međunarodne organizacije imaju sve veću ulogu i samim tim njihov značaj raste. Ipak, postoji jedna organizacija koja je navedeni subjektivitet učvrstila - u pitanju su naravno Ujedinjene nacije. Šta čini Ujedinjene nacije tako posebnim $u$ odnosu na ostale međunarodne organizacije, ali i na ostale aktere međunarodnog prava?
\end{abstract}

Ključne reči: međunarodne organizacije, međunarodni odnosi, puna i delimična pravna ličnost, države.

\footnotetext{
${ }^{1}$ Nauči saradnik, Institut za međunarodnu politiku i privredu, e-mail adresa: marko@diplomacy.bg.ac.rs.
}

Rad je nastao u okviru naučnoistraživačkog projekta „Srbija i izazovi u međunarodnim odnosima 2020. godine“, koji finansira Ministarstvo prosvete, nauke i tehnološkog razvoja Republike Srbije, a realizuje Institut za međunarodnu politiku i privredu tokom 2020. godine. 


\section{UVOD}

Nastanak i razvoj međunarodnih organizacija predstavlja odličan pokazatelj na koji način se međunarodno pravo transformiše i menja, čak i svoju suštinu, u skladu sa potrebama i promenom okolnosti $u$ međunarodnim odnosima. Kada su prvi embrionalni oblici međunarodnih organizacija nastajali u XIX veku, retko ko je mogao da pretpostavi da će se već sredinom narednog veka, legitimnost i državnost neke države ceniti i na osnovu članstva u jednoj međunarodnoj organizaciji - Ujedinjenim nacijama (UN). Ipak, heterogenost međunarodnih organizacija, njihova drugačija svrha, uloga ili cilj svakako određuju i njihov uticaj i konsekventno značaj na međunarodnopravnoj pozornici. Stoga je važno razumeti evoluciju međunarodnih organizacija, kako bi se i njihova uloga danas sagledala u celosti i na odgovarajući način. Ovo ne predstavlja (samo) frazu koju često možemo videti u udžbenicima, već činjenicu da se danas olako, često i najčešće bez osnova, a svakako bez potrebnog razumevanja samih međunarodnih organizacija i njihovog nastanka, kritikuju međunarodne organizacije i njihova uloga u današnjim međunarodnim odnosima.

\section{NASTANAK MEĐUNARODNIH ORGANIZACIJA}

Zašto i kako su nastale međunarodne organizacije i njihove prethodnice je jasno - zbog razvoja međunarodne saradnje i potrebe za intenzivnijom $i$, pre svega, konstantnijom komunikacijom, a sve kao posledica društvenih promena. Ipak, razvoj jedne organizacije dostigao je posebne, neslućene razmere - $u$ pitanju su, naravno, Ujedinjene nacije. Šta je dovelo do tako velike, sveobuhvatne, i na kraju krajeva, moćne organizacije, koja je jedina donekle poremetila do tada aksiom o apsolutnom primatu država $u$ međunarodnim odnosima i međunarodnom pravu, istražićemo upravo u ovom radu.

Razvoj saradnje između država predstavlja neophodan, ekonomski element. On se pojavio sa pojavom industrijske revolucije. Pre svega $u$ periodu Unija, dakle početkom XX veka, ljudi su se, što kroz međudržavne što kroz nevladine organizacije, udruživali kako bi 
pospešili rad svojih preduzeća i povećali profite. Ekonomski element se dovoljno razvio kada je cena koštanja rata postala mnogo veća od benefita saradnje između država. Na tim osnovama je nastala i Evropska unija.

Ideja globalnog mira, dokumentovana je i elaborirana još u delima Platona, rimskih filozofa i na dalje, sve do današnjih dana. Štaviše, ona je neizostavni deo svake epohe, ali njena snaga je bila prviše mala da bi ideja mira uticala na politički život jednog društva a kamoli više njih. Takva situacija je bila sve do sredine XVII veka. U tom periodu došlo je do usvajanja ideja globalnog mira kako na praktičnom planu tako i na širem teorijskom polju. Prvi proboj ostvaren je Vestfalskim mirom. Taj sporazum je bio značajan jer je to prvi globalni mir, verifikovan jednim međunarodnim ugovorom (ideja globalnog mira, na prostoru tadašnje spoznaje globalnog, dakle na prostoru Evrope). Retko koji datum ili događaj uopšte se doživljava kao prekretnica u razvoju međunarodnog prava, a u isto vreme i kao prekretnica u međunarodnim odnosima, kao što je to potpisivanje Vestfalskog sporazuma 1684. godine. Ipak, širi kontekst je veoma važan, a vremenom taj, bez ikakve dileme, značajan datum poprimio je romantizirane odlike kroz prikazivanje borbe hegemonističkih habzburgovaca i država u borbi za svoju nezavisnost, poput Švedske, Danske itd. Iako bi ovako postavljen sled događaja bio vrlo praktičan, postoje ozbiljna razmišljanja koja dovode u sumnju mnoge detalje. ${ }^{2}$ Ipak, i pored nekih neospornih preterivanja $u$ isticanju revolucionarnog karaktera ovog događaja, smatramo da je on, uz još nekoliko političko-društvenih faktora, stvarno bio deo početka razvoja međunarodnih organizacija. Tako je i u Vestfalskom miru, proklamovano u članu 123 That nevertheless the concluded Peace shall remain in force, and all Partys in this Transaction shall be oblig'd to defend and protect all and every Article of this Peace against any one, without distinction of Religion; and if it happens any point shall be violated, the Offended shall before all things exhort the Offender not to come to any Hostility,

\footnotetext{
${ }^{2}$ Vidi Andreas Osiander, "Sovereignty, International Relations, and the Westphalian Myth", International Organization, Vol. 55, No. 2, pp. 251-281; kao i Stephen Krasner, "Westphalia and All That", u: Judith Goldstein and Robert O. Keohane (eds), Ideas and Foreign Policy: Beliefs, Institutions and Political Change, Ithaca, N.Y.: Cornell University Press, 1999, pp. 235-264.
} 
submitting the Cause to a friendly Composition, or the ordinary Proceedings of Justice. ${ }^{3}$ Ideal univezalnog mira je proklamovan u preambuli i prvom članu ovog ugovora, ${ }^{4}$ a ta ideja se proteže nadalje kroz ceo tekst. Ideal mira, prvi put prihvaćen na jednom globalnom nivou toga vremena, je ono što izdvaja Vestfalski mir od svih prethodnih sličnih događaja. I konačno, ovde dolazi i do postavljanja temelja egalitarnog sistema, bez razlika između vera, katolika ili protestanata. ${ }^{5}$

$\mathrm{U}$ isto vreme $\mathrm{u}$ mnogim naučnim delima, autora poput Huga Grocijusa, pre svih De jure belli ac pacis, značaj ovog dela uzdignut je na najviši pijedestal među međunarodnim pravnicima i često se koristi, $t j$. predstavlja prekretnicu u razvoju, odnosno nastanku modernog međunarodnog prava. Često su se mogla čuti razmišljanja poput onog da je Hugo Grocijus prilagodio staro prirodno pravo kako bi popunio prazninu nastalu nestankom vrhovne vlasti Vladara i Pape. ${ }^{6}$ Ipak, nećemo se zadržavati na opštem značaju Huga Grocijusa i njegovih radova na razvoj međunarodnog prava, iako je njegov značaj nesumnjivo veliki. Konkretizovaćemo naš osvrt na jednakost, ali pre svega koren pacifističkog pogleda na svet koji je omogućio nastanak organizacija globalnog karaktera sa svetskim mirom kao osnovnom težnjom, na osnovu kojih su nastale sve faze $u$ razvoju međunarodnih organizacija koje su krunisane stvaranjem Ujedinjenih nacija.

Daleko od toga da je Grocijus bio jedini ili čak prvi koji je razmatrao ova pitanja. Često su u naučnoj literaturi i analizama brojni veliki umovi u senci velikog holandskog internacionaliste, iako je i njihov značaj bio izuzetno veliki i od kojih je Hugo Grocijus mnoge ideje usvojio ili dodatno razradio. Njihove pacifističke ideje u tom dobu takođe su imale veliki uticaj, a to su bili Alberiko Gentilis, Fransoa Suarez, ili recimo

\footnotetext{
${ }^{3}$ Vestfalski ugovor, član 123, http://avalon.law.yale.edu/17th_century/west phal.asp, pristupljeno 14.12.2013.

${ }^{4}$ Ibid.

${ }^{5}$ Leo Gross, "Peace of Westphalia, 1648-1948", American Journal of International Law, Issue 42, No 2, p. 22.

${ }^{6}$ Percy Henry Winfield, The Foundations and the Future of International Law, Cambridge Universtiy Press, 1941, p. 20.
} 
najstariji od svih pre-grocijanaca, ali možda i najnapredniji po svom humanističkom pristupu - Fransoa de Vitorij. Naravno, sve ove ideje treba posmatrati u kontekstu vremena i okolnosti.

Pored ideje globalnog mira, često su se mogle čuti i ideje o opravdanosti i štaviše, neophodnosti i moralnosti rata. Navešćemo samo Prudona, oca anarhizma, koji se posebno isticao veličanjem moralnosti rata, te kaže da rat „jača moral, vrši se preporod naroda, države se uravnotežuju, napredak se nastavlja, pravda utvrđuje svu moć, sloboda nalazi svoje garantije". ${ }^{7}$ Rat je, shodo tome, dugo smatran kao jedan od načina za rešenje spora, potpuno legitiman. Štaviše, u ne tako davnim vremenima on je bio osnovni i primarni način rešavanja sukoba između država. Ljudi su $u$ to vreme verovali $u$ višu silu, $u$ pravu, na jednom neposrednom, direktnom nivou. Verovali su da će ulaskom $u$ rat pobediti ako su u pravu, bez obzira na svoju slabost, i snagu i nadmoćnost protivnika. Legende nastale na tim verovanjima, ali i kao posledice istih, su mnogobrojne - imamo priče o Davidu i Golijatu, spartanske legende itd. U današnjem svetu, rat gubi svaku legitimnost. ${ }^{8}$ Rat ne može biti rešenje, zato što "rat nije u stanju da ustanovi pravo“. ${ }^{9}$ Jednostavno, rat kao način rešavanja sukoba je pregazilo vreme. U teoriji to je nedvosmisleno. Ali, koliko će vremena proći da se to ostvari i u praksi veliko je pitanje, a odgovor može biti samo neodređen - kada čovek kao vrsta dovoljno evoluira. Međutim, revolucionarni potezi grupe ljudi, mogu ubrzati taj put ili ga barem učiniti lakšim. Ali, kada je društvo dovoljno sazrelo da uvidi izlišnost rata, tačnije važnost njegovog odsustva, napravljen je prvi korak ka stvaranju međunarodnih organizacija, kao osnovnog i najvažnijeg vida institucionalizovane saradnje država. Otuda su i osnovane Ujedinjene nacije upravo na ideji globalnog mira, i zato u Povelji UN stoji „MI, NARODI UJEDINJENIH

\footnotetext{
${ }^{7}$ Proudhon, Les Soirees de Saint-Petersbourg, Lyon, 1842, t. II, p. 26 u: Mihailo Ilić, Opšta razmatranja o Društou naroda i njegovom pravu: doktorska teza, Pravni fakultet Univerziteta u Beogradu, Beograd, 1996, str. 102.

${ }^{8}$ Kako to lepo kaže Mihailo Ilić kao odgovor na Prudonovu konstataciju da rat iza sebe ima činjenicu - trajanje od šest hiljada godina, da postoji jedna druga činjenica - evolucija.

${ }^{9}$ Ibid., 113.
} 
NACIJA rešeni da spasemo buduća pokoljenja užasa rata, koji je dvaput $\mathrm{u}$ toku našeg života naneo čovečanstvu neopisive patnje, i da ponovo potvrdimo veru $u$ osnovna prava čoveka, $u$ dostojanstvo i vrednost ljudske ličnosti, u ravnopravnost ljudi i žena i nacija velikih i malih, i da obezbedimo uslove pod kojima će moći da se očuvaju pravda i poštovanje obaveza koje proističu iz ugovora i drugih izvora međunarodnog prava, kao i da radimo na socijalnom napretku i poboljšanju životnih uslova u većoj slobodi i u tom cilju da budemo trpeljivi i da zajedno živimo u miru jedni s drugima kao dobri susedi, i da ujedinimo svoje snage radi održanja međunarodnog mira i bezbednosti, i da obezbedimo, prihvatanjem načela i ustanovljenjem metoda, da se oružana sila ne upotrebljava izuzev u opštem interesu, i da koristimo međunarodni mehanizam $u$ svrhu unapređenja ekonomskog i socijalnog napretka svih naroda, odlučili smo da udružimo svoje napore radi ostvarenja ovih ciljeva. Saglasno tome, naše odnosne vlade, posredstvom svojih predstavnika okupljenih u gradu San Francisku, koji su podneli svoja punomoćja $\mathrm{u}$ ispravnom i propisnom obliku, usvajaju ovu Povelju Ujedinjenih nacija i osnivaju međunarodnu organizaciju koja će se zvati Ujedinjene nacije."

Razvoj međunarodnog prava jeste neodvojivo povezano upravo idejom mira. Neki autori idu dotle da kažu da je „mir svakako ključna preokupacija i međunarodnog prava i teorije i prakse međunarodnih odnosa“ ${ }^{10}$ Za mir se svakako može reći da je krajnji cilj međunarodnog prava, i najveći napori upravljeni su upravo prema tom cilju. Međunarodno pravo, kao oruđe za regulisanje međunarodnih odnosa ali i dostizanja mira, prestavlja conditio sine qua non stvaranja međunarodnih organizacija. Već pomenuti Vestfalski sporazum 1648. doneo je mnoge promene na polju međunarodnih odnosa od kojih su mnoge preuveličane, mitologizirane pa čak i potpuno pogrešno interpretirane, ${ }^{11}$ ali se to ne može reći za uticaj na međunarodno pravo.

${ }^{10}$ Branko Rakić, Ostvarivanje mira preko međunarodnog organizovanja i integrisanja država, Pravni fakultet Univerziteta u Beogradu, Beograd, 2009, str. 9.

${ }^{11}$ Videti detljnije $\mathrm{u}$ Thomas G. Weiss, "International Bureaucracy: the myth and reality of the international civil service", International Affairs, Vol. 58, No. 2, pp. 287-300. 
Naime, nimalo slučajno, nekih četvrt veka ranije, Hugo Grocijus je objavio delo De Iure belli ac pacis, koje se i danas smatra za prekretnicu u razvoju međunarodnog prava.

Ideja ravnopravnosti predstavlja još jednu ideju važnu za nastanak Društva naroda i kasnije Ujedinjenih nacija, i da ponovo potvrdimo veru u osnovna prava čoveka, u ravnopravnost ljudi i žena, i nacija velikih i malih, i da obezbedimo uslove pod kojima će moći da se očuvaju pravda i poštovanje obaveza koje proističu iz ugovora, i njen razvoj se zgodno može povezati sa razvojem ideje pacifizma. Globalno posmatranje sveta, a ne posmatranje istog kroz evropsku vizuru, predstavlja još jedan neophodan element. On je ipak bio moguć tek razvojem saradnje između država. Ovo je upravo i krucijalni element koji povezuje sve prethodno navedene elemente. Saradnja između država je dovela do razvoja međunarodnog prava, do ravnopravnog pogleda jednih na druge, i na kraju do želje da se sukobi između njih u budućnosti izbegnu. Izolacionizam, strah od nepoznatog, koji na mikro planu ljudskih odnosa dovodi do najiskrivljenijih pogleda na stvarnost, na isti način je delovao i na međunarodne odnose kroz istoriju.

Rat kao inicijalna kapisla - Svi navedeni elementi za nastanak međunarodnih organizacija imaju barem donekle ideju mira u sebi, pa je i sama ideja mira inherentna ovoj pojavi. Ipak, kako samo život ume da bude ironičan, ni međunarodno pravo u ovom obliku u kojem ga danas izučavamo, ni međunarodne organizacije, ali ni same Ujedinjene nacije, ne bi postojale da nije bilo rata. I to ne rata samo kao nekog idealizovanog i generalizovanog sukoba koji treba izbeći, već upravo su konkretni ratovi odigrali ključne uloge u nastanku mnogih elemenata koje smo pominjali. Ipak, ne oduzimajući ni najmanje na važnosti ovog dela, možemo sa sigurnošću reći da je Vestfalski mir, kao direktna posledica 30-ogodišnjeg rata, doveo do sprovođenja njegovih ideja u stvarnosti i na taj način i do prelaska sa teorijskog razmatranja na realnu primenu - što je predstavljalo svojevrstan presedan. Isto tako, kongres u Utrehtu, veoma značajan za istoriju zapadne Evrope, bio je posledica rata za špansko nasleđe, nakon Napoleonovih krvavih ratova održan je Bečki kongres 1814-1815, zatim je Krimski rat inicirao Pariski kongres 1856. godine. Istorija se ponovila i kada je Društvo naroda u pitanju. Opet je 
rat uspeo da napredne ideje o marginalizaciji rata promoviše u praksi, ali je upravo rat samo tri decenije kasnije nadvladao pacifističke težnje. I posle Drugog svetskog rata, opet je došlo do dodatnog napretka - rat je kao način rešavanja spora potpuno stavljen van prava. Iz ove kratke retrospektive možemo zaključiti da ako je historiae magistra vitae est, ljudi su svakako jako loši đaci, ili bolje reći, večiti ponavljači. Takođe, očigledno je da su kroz istoriju veliki civilizacijski koraci i uspesi bili nepobitno uslovljeni krvavim ratovima. Čini se da ljudi jedino cene mir, kada im je rat u svežem sećanju. Upravo zato je vitalna uloga međunarodnih organizacija i kao elementa stalnosti tih organizacija, da rade na podsećanju koliko je mir važan i dragocen, ali i koliko je u isto vreme krh.

\section{DRUŠTVO NARODA}

Ujedinjene nacije predstavljaju vrhunac razvoja međunarodnih organizacija, ali pitanje je da li bi do nastanka UN došlo, a pogotovo da li bi do tog razvoja došlo tako brzo da nije bilo prethodnice UN - Društva naroda. Zato je svrsishodno istražiti kako je došlo do stvaranja Društva naroda, kao neposredne prethodnice UN i organizacije iz koje je UN preuzeo većinu sistemskih rešenja.

Društvo naroda predstavlja prvu organizaciju globalnog karaktera koja za cilj ima održavanje mira, odnosno sprečavanje rata. Društvo naroda je bila organizacija globalnog karaktera, $\mathrm{u}$ to nema nikakve dileme. Ali, ne može se reći da je bila globalna. Društvo naroda su osnovale 42 države, a njihov broj je kasnije porastao do broja 58, što pokazuje jedan značajan broj država koji je pristupio novom obliku udruživanja. Ipak, ne možemo reći da je Društvo naroda predstavljalo globalnu organizaciju. Ne znači da je za globalnu organizaciju neophodno da sve države sveta budu članovi, ali odsustvo jedne supersile, kao što su Sjedinjene Američke Države (SAD) svakako predstavlja preveliki nedostatak. Paradoks (ne)članstva SAD u Društvu naroda je utoliko veći zbog činjenice da je pitanje da li bi bez velikog angažovanja tadašnjeg predsednika SAD, Tomasa Vudroa Vilsona, Društvo naroda uopšte nastalo. Ipak, malo zbog uticaja raznih nacionalnih grupa u tadašnjem američkom društvu, malo 
zbog grešaka koje je sam Vilson i njegov kabinet napravio, pre svega $\mathrm{u}$ izazivanju ili barem produbljivanju antagonizma sa republikanskom partijom, odnosno bukvalno stavljanjem republikanaca u red onih koji se protive ulasku SAD u Društvo naroda, one nikad nisu dospele tamo. Takođe, Nemačka je pristupila Društvu naroda tek 1926, SSSR tek 1936, a u međuvremenu je Japan, posle mnogo uslovljavanja i pretnji, istupio iz Društva naroda 1933. (inicijalna kapisla za istupanje bila je rezolucija skupštine u kojoj se preporučuje povlačanje japanskih trupa iz Mandžurije i kineski suverenitet nad tom spornom teritorijom). Nestalni karakter članstva, možda najbolje oslikava stalno ucenjivanje Poljske istupanjem iz organizacije ako ne dobije mesto u savetu Društva naroda. Ipak, iako je globalni karakter Društva naroda teško braniti, s druge strane teško možemo govoriti uopšte o međunarodnim organizacijama pre Društva naroda. ${ }^{12}$ Izraz međunarodna organizacija označava oblik povezivanja država, uspostavljen međunarodnim ugovorom, koji poseduje ustav i zajedničke organe, koji ima različitu ličnost od ličnosti njegovih država članica i koji je subjekt međunarodnog prava sa sposobnošću zaključenja ugovora. ${ }^{13}$ Kao što smo razmotrili, rat je kroz istoriju čovečanstva bio jedan legitimni način državne politike i rešavanje nesporazuma. Sve do pojave Društva naroda, takvo stanje je trajalo. Kako kaže Ilija Pržić, „Odricanje od rata u međunarodnim odnosima je nova pojava. Sve do svetskog rata nije moglo biti ni reči o ovome. Danas, međutim, to je aktuelno pitanje konkretne politike i jedan od najvažnijih elemenata novog pravnog sistema, potvrđen $\mathrm{u}$ međunarodnim ugovorima. Prvi veliki međunarodni akt $\mathrm{u}$ kome je, iako nepotpuno, izražena ideja o odricanju od rata kao uobičajnog sredstva za rešavanje

12 "However, international organization did not be-come an identifiable, systematic area of inquiry until the creation of the League of Nations in 1920, following World War I..." u: J. Martin Rochester, "The Rise and Fall of International Organization as a Field of Study", International Organization, Vol. 40, No. 4, p. 779.

${ }^{13}$ Le droit des traits, Document A/CN.4/101, Rapport de G.G. Fitzmaurice, rapporteur special, 14 mars 1956, l'Annuaire de la Commission du droit international, 1956, col.II, str 110, preuzeto sa internet sajta Komisije za međunarodno pravo, prevod preuzet od: Rakić, Branko, Ostvarivanje mira preko međunarodnog organizovanja i integrisanja država, Pravni fakultet Univerziteta $u$ Beogradu, Beograd, 2009, str. 13. 
međunarodnih sporova, je pakt Društva naroda. ${ }^{14}$ Upravo tako, iako je u članu 5 Društva naroda ostavljena mogućnost rata, kroz celu povelju, od uvoda do samih članova, provejavaju ideje o uspostavljanju mira, obaveza o izbegavanja rata, i sl. U potpunoj zabrani rata najdalje je otišao Kelogov pakt. Poseban značaj Kelogovog pakta je činjenica da su njemu pristupile iSAD, SSSR, Turska i $\mathrm{dr}^{15}$

\section{NAZIV - DRUŠTVO NARODA ILI LIGA NARODA}

Dva različita naziva preteče Ujedinjenih nacija potiču od prevoda. Društvo naroda bilo uobičajno za neke naše pravnike, poput Mihaila Ilića, ${ }_{1}^{16}$ Milete Novakovića, ${ }^{17}$ Ilije A. Pržića, ${ }^{18}$ Slavka M. Ćirića ${ }^{19}$ koji su bili pod značajnim uticajem francuskog jezika, a čiji je prevod upravo ovaj naziv Société des Nations. S druge strane, naziv Liga naroda (od engleskog naziva League of Nations) je takođe imala svoje zagovornike još od prvih godina osnivanja ove organizacije. Ovaj naziv su koristili recimo Juraj Andraši, ${ }^{20}$ Lazar P. Marković, ${ }^{21}$ Đura Popović ${ }^{22}$. Takođe, pojavljivao se i naziv Liga nacija, ${ }^{23}$ a ni to da neki autori koriste oba naziva, poput

${ }^{14}$ Ilija A. Pržić, „Britanski model za izmenu pakta Društva naroda“", Arhiv za pravne i društvene nauke, 1930, knjiga XXI (XXXVIII), br. 3, str. 216.

${ }^{15}$ Videti detaljnije Ilija A. Pržić, "Kelogov pakt", Arhiv za pravne i društvene nauke, 1929, knjiga XVII (XXXV), br. 2., str. 124.

${ }^{16}$ Mihailo llić, Opšta razmatranja o Društou naroda i njegovom pravu: doktorska teza, op. cit.

${ }^{17}$ Mileta Novaković, Društvo naroda, Štamparija Mirotočivi, Beograd, 1922.

${ }^{18}$ Ilija A. Pržić, „,Britanski model za izmenu pakta Društva naroda“ , Arhiv za pravne i društvene nauke, 1930, knjiga XXI (XXXVIII), br. 3, str 216.

${ }^{19}$ Slavko M. Ćirić, Društvo naroda, Novi Sad: Slavija, 1928; Slavko M. Ćirić, Ulazak Nemačke u Društvo naroda, (ur. Antonije Hadžić), Letopis Matice srpske, 1926, str. 303-304.

${ }^{20}$ Juraj Andraši, Liga naroda: njezino ustrojstvo i djelovanje, Izdanje Pramatice nakladnoga k. d. Petar Kvaternik i drugovi, Zagreb, 1931.

${ }^{21}$ Lazar P. Marković, Liga naroda i grčko-italijanski sukob, Beograd, 1923.

${ }^{22}$ Đura Popović, Liga naroda - njen postanak, uređenje i rad, Srpska književna zadruga, 1930.

${ }^{23}$ Vladislav Marjanović, Jugoslavija, Liga nacija $i$ ideja mira $i$ međunarodnog sporazumevanja 1925-1929, Beograd, 1978. 
Milenka Vesnića ${ }^{24}$ ili Antuna M. Petrinčića, ${ }^{25}$ nije bilo neuobičajno. U radu se koristi naziv Društvo naroda, ne zbog bilo kakve jezičke konotacije ili anglo-saksonskih preferencija, već upravo zbog onoga šta reč društvo našem jeziku označava, odnosno ono što Liga ne označava. U potpunosti se slažemo sa Đurom Popovićem ${ }^{26}$ kada kaže da ne treba da gledamo sa kog jezika treba prevesti naziv, da li sa engleskog od koga bi bila Liga naroda ili sa francuskog čiji prevod je Društvo naroda. Treba obratiti pažnju na to šta neka reč znači. Ipak, iako na istim polaznim premisama u ovom radu se nudi drugačiji zaključak nego u delima Đure Popovića. Veliku ulogu u tome je odigrala i vremenska diskrepanca od preko 70 godina. Naime, Popović je u svojoj knjizi naveo da je "društvo pojam privatnog prava i kao takav tačno definisan, on naime pretpostavlja jedan element lukrativnog cilja bez koga u pravnom smislu nema društva, a kao takav on ni najmanje ne odgovara sadašnjoj međunarodnoj organizaciji. Reč liga, mada stranog porekla, ušla je u naš jezik kao mnoge druge (ideal, politika, teorija itd). Njen smisao pak nije pravno tačno određen i zato se ona vrlo zgodno daje primeniti na ustanovu koja je stvorena Paktom od 1919. godine“ ${ }^{27}$ Ipak, reč Liga se u međuvremenu kod nas razvila u pravcu u kome nikako ne odgovara liberalnom zanosu u kome je donet, kako Pakt tako i stvorena Liga naroda. Liga prvenstveno ukazuje na jednu vrstu takmičenja u kojoj postoje pobednici, oni koji ispadaju itd. Štaviše, čak i u tom vremenu, društvo je pre ukazivalo na jednakost nego na pomenutu osobinu društva iz građanskog prava. Iz navedenih razloga koristićemo naziv Društvo naroda.

Moramo ipak istaći da ona biva koncipirana i dobija smisao, ali nije nastala. Njen nastank nije sprečen ničim drugim, do prirodom društva u kome je postojalo Društvo naroda. Možemo reći da je međunarodna administracija nastala i postala onakva kakva je zamišljena 1919, tek nastankom ali i razvojem njenog naslednika - Ujedinjenih nacija pravi

\footnotetext{
${ }^{24}$ Milenko Vesnić, O Društvu naroda, Geca Kon, Beograd, 1920.

${ }^{25}$ Antun M. Petrinčić, „,O Društvu naroda (Uzroci dosadašnje pasivnosti)“, Sveske broj 70, 2003, dostupno na http://www.malinemo.rs/sveske/sveske-broj-70decembar-2003.

${ }^{26}$ Đura Popović, Liga naroda - njen postanak, uređenje i rad , op. cit., str. 51.

${ }^{27}$ Ibid.
} 
se pravi iskorak i "kill point" u odnosima između subjekata međunarodnog prava.

\section{UJEDINJENE NACIJE}

Organizacija ujedinjenih nacija nastala je na konferenciji u San Francisku, 24. oktobra 1945. godine. Ona je prirodni naslednik Društva naroda i predstavlja prvu globalnu organizaciju. ${ }^{28}$ Članice UN su sve potpuno priznate države na svetu. Poslednja država je Južni Sudan, koja je na predlog Saveta bezbednosti ${ }^{29}$ primljena kao punopravna, 193. članica članica UN dana 14. jula 2011. godine. ${ }^{30}$ UN predstavljaju najznačajniju i najveću međunarodnu organizaciju u istoriji čovečanstva, ili kako neki autori to ističu i ,"najviši oblik međunarodne organizacije“ ${ }^{31}$ Štaviše, to je organizacija koja je u nekim aspektima nadmašila države. Prijem države $u$ članstvo UN znači više za priznanje države, nego priznanje bilo koje pojedinačne države. Kada su međunarodne organizacije nastajale, početkom XX veka, verujemo da je ovakav ishod, odnosno odnos originernog i derivativnog subjekta međunarodnog prava, malo ko mogao da predvidi.

Jedan od razloga liberalnijeg stava država, tradicionalno nevoljnih da prepuste jurisdikciju nad teritorijom ili licima zarad neke globalne dobrobiti, možemo videti i u vremenu nastanka UN u odnosu na Društvo naroda. Ono što se na početku, prilikom stvaranja Ujedinjenih nacija, lako uočava kao razlika jeste da je konferencija u San Francisku održana za vreme Drugog svetskog rata, dok je Versajski sporazum postignut nakon okončanja sukoba u Prvom svetskom ratu. Ova razlika

${ }^{28} \mathrm{Za}$ razliku od Društva naroda koja je bila organizacija globanog karktera ali ne i globalna, prim aut.

${ }^{29}$ http:/ / www.un.org/apps/news/story.asp/story.asp?NewsID=39026\&Cr= south+sudan\&Cr1=\#.UydFnPldUmk.

${ }^{30}$ http:/ / www.un.org/apps/news/story.asp?NewsID=39034\&Cr=South+Sudan\& Cr1=\#.UydEj_ldUmk.

${ }^{31}$ Perrenoud, Regime des privileges des missions diplomatiques et des Organisations Internationales en Suisse, str. 60, u Milenko Kreća, Međunarodno pravo predstavljanja (diplomatsko i konzularno pravo), Beograd, 2014, str. 206. 
može na prvi pogled delovati više kao neka istorijska zanimljivost, bez većeg uticaja na suštinu tih sporazuma, ali je njen značaj u teoriji međunarodnog prava i međunarodnih organizacija jasan i veoma očigledan. Tvorci Društva naroda morali su da imaju, kao okvir, prilikom projektovanja nove organizacije Versajski sporazum. Mnogi postulati budućeg poretka tu su već bili određeni, tako da je manevarski prostor za kreatore bio značajno sužen. Takođe, misli državnika su mnogo više bile okrenute ka nacionalnim pitanjima, obnovi svojih država, što je potpuno razumljivo. $S$ druge strane, tvorci Ujedinjenih nacija nisu morali da se bore i pokoravaju ovim stegama. Naprotiv, oni su mogli da koriste, i slobodno možemo reći da su u dobroj meri i iskoristili, tu slobodu ali i polet u pogledu izgradnje budućeg sveta kad se završi rat. Liga naroda je nastajala u sadašnjosti dok su Ujedinjene nacije projektovane za budućnost, jedan drugi svet, te su samim tim lakše prihvaćene neke ambiciozne i revolucionarne teze i postulati, koji ne bi bili usvojeni da su predloženi u drugom vremenskom kontekstu. Na tom talasu optimizma (uz obezbeđenu dominaciju velikih sila kroz Savet bezbednosti) UN su zauzele značajnu poziciju u međunarodnim odnosima, koja se posebno ogleda u ulozi kod priznanja država.

\section{ČLANSTVO U UN}

U pravnoj teoriji postoje brojne podele između aktera međunarodnog prava, ali jedna od posebnog značaja za ovo pitanje jeste podela na aktere sa punom i delimičnom pravnom ličnosti. Ova podela se najbolje može videti u okviru presude MSP "Reparation for Injuries" u okviru koje se eksplicitno navodi da subjekti prava u bilo kom pravnom sistemu nisu nužno identični u svojoj prirodi i u kontekstu svojih prava. Tako se države smatraju jedinim potpunim akterima, a ta potpunost se ogleda u činjenici da imaju, ili barem mogu imati, sva prava i preuzeti sve obaveze u međunarodnopravnom sistemu. $S$ druge strane, ostali učesnici poput međunarodnih organizacija ili pojedinca imaju samo neke elemente koji su im povereni od strane država. Međunarodne organizacije ne predstavljaju originerne subjekte međunarodnog prava - originerni subjekti su isključivo države, ali 
vremenom međunarodne organizacije imaju sve veću ulogu i samim tim njihov značaj raste. $U$ tome se posebno ističu Ujedinjene nacije. One, pored mnogih drugih prerogativa, imaju jedan za koji se čini da u svojoj biti nadmašuje i same države - u pitanju je činjenica da se prijemom države u Ujedinjene nacije njena državnost potvrđuje.

Postupak prijema članice u Ujedinjene nacije izgleda ovako:

Država podnosi molbu generalnom sekretaru i pismo u kom formalno navodi da prihvata obaveze iz Povelje. Savet bezbednosti razmatra molbu. Svaka preporuka za prijem mora dobiti saglasnost 9 od 15 članova Saveta bezbednosti, pod uslovom da nijedna od njegovih pet stalnih članica Kina, Francuska, Ruska Federacija, Ujedinjeno Kraljevstvo i Sjedinjene Američke Države - nisu protiv. Ako Savet bezbednosti preporuči prijem, preporuka se predstavlja Generalnoj skupštini na razmatranje. USkupštini je potrebna dvotrećinska većina za prijem nove države, dok članstvo stupa na snagu danom usvajanja rezolucije o prijemu.

Da li ova praksa, u kojoj UN odlučuju o državnosti država, znači da su one postale u tom domenu značajnije od samih država?

Odgovor je negativan - naime, kao što se vidi iz rada samih UN one predstavljaju pre svega "facilitaciju" rada država, forum za razmenu mišljenja i donošenje odluka (sa posebno značajnim mestom za stalne članice Saveta bezbednosti).

Jedini element međunarodnih organizacije, koji ima svoju odvojenost i posebnost u odnosu na države članice, jeste administracija. Ona je nastala kao taj neophodni element stalnosti između zasedanja, a u međuvremenu je razvila svoja pravila i uzanse funkcionisanja, ali i nezavisnosti i samostalnosti u radu. Ipak, čak i ovaj nezavisni element predstavlja izuzetak koji je napravljen da bi organizacija efikasno funkcionisala - a ne da bi joj se dale značajnije samostalne ingerencije.

\section{ZAKLJUČAK}

Dva zaključka o ulozi UN u međunarodnim odnosima su neizbežna i nedvosmislena. Pre svega, u organizacionom, strukturnom, istorijskom i političkom smislu Ujedinjene nacije predstavljaju najznačajniju 
organizaciju i vrhunac razvoja međunarodnih organizacija. U nekim elementima one su dostigle nivo država - u svom značaju, u svom uticaju na odnose, te se moze zaključiti da su u odnosu na druge međunarodne organizacije doista izuzetak.

S druge strane, ne treba smetnuti sa uma da su i Ujedinjene nacije, ma koliko bile značajna i razvijena organizacija, ipak u krajnjoj instanci odraz volje država. Međunarodne organizacije isključivo funkcionišu kao otelotvorenje volje država članica. To treba imati na umu i kada se kritikuju potezi međunarodnih organizacija ili njihova uloga - obe stvari predstavljaju samo odraz volje država. Jedini izuzetak predstavlja administracija - a ovde se posebno ističe opet administracija UN na čelu sa Generalnim sekretarom. Njima je data nezavisnost $u$ radu i to je jedini element $u$ kome neposredna volja država članica jeste donekle ograničena.

\section{LITERATURA}

Andraši, Juraj, Liga naroda: njezino ustrojstvo i djelovanje, Izdanje Pramatice nakladnoga k. d. Petar Kvaternik i drugovi, Zagreb, 1931.

Ćirić, Slavko M., Društvo naroda, Novi Sad: Slavija, 1928.

Ćirić, Slavko M., Ulazak Nemačke u Društvo naroda, (ur. Antonije Hadžić), Letopis Matice srpske, 1926.

Gross, Leo, "Peace of Westphalia, 1648-1948", American Journal of International Law, Issue 42, No 2.

Ilić, Mihailo, Opšta razmatranja o Društou naroda i njegovom pravu: doktorska teza, Pravni fakultet Univerziteta u Beogradu, Beograd, 1996.

Krasner, Stephen, "Westphalia and All That", u: Judith Goldstein and Robert O. Keohane (eds), Ideas and Foreign Policy: Beliefs, Institutions and Political Change, Ithaca, N.Y.: Cornell University Press, 1999, pp. 235-264.

Kreća, Milenko, Međunarodno pravo predstavljanja (diplomatsko i konzularno pravo), Beograd, 2014.

Marjanović, Vladislav, Jugoslavija, Liga nacija i ideja mira i međunarodnog sporazumevanja 1925-1929, Beograd, 1978. 
Marković, Lazar P., Liga naroda i grčko-italijanski sukob, Beograd, 1923.

Novaković, Mileta, Društvo naroda, Štamparija Mirotočivi, Beograd, 1922.

Osiander, Andreas, "Sovereignty, International Relations, and the Westphalian Myth", International Organization, Vol. 55, No. 2, pp. 251-281.

Petrinčić, Antun M., „O Društvu naroda (Uzroci dosadašnje pasivnosti)“, Sveske broj 70, 2003, dostupno na http://www.malinemo.rs/sveske /sveske-broj-70-decembar-2003.

Popović, Đura, Liga naroda - njen postanak, uređenje i rad, Srpska književna zadruga, 1930.

Pržić, Ilija A., „Britanski model za izmenu pakta Društva naroda“, Arhiv za pravne i društvene nauke, 1930, knjiga XXI (XXXVIII), br. 3.

Pržić, Ilija A., ,"Britanski model za izmenu pakta Društva naroda“, Arhiv za pravne i društvene nauke, 1930, knjiga XXI (XXXVIII), br. 3.

Pržić, Ilija A., „Kelogov pakt”, Arhiv za pravne i društvene nauke, 1929, knjiga XVII (XXXV), br. 2., str. 124.

Rakić, Branko, Ostvarivanje mira preko međunarodnog organizovanja $i$ integrisanja država, Pravni fakultet Univerziteta u Beogradu, Beograd, 2009.

Rochester, J. Martin, "The Rise and Fall of International Organization as a Field of Study", International Organization, Vol. 40, No. 4, p. 777-813.

Vesnić, Milenko, O Društvu naroda, Geca Kon, Beograd, 1920.

Vestfalski ugovor, član 123, http:/ / avalon.law.yale.edu/17th_century/ westphal.asp; pristupljeno 14.12.2013.

Weiss, Thomas G., "International Bureaucracy: the myth and reality of the international civil service", International Affairs, Vol. 58, No. 2, pp. 287-300.

Winfield, Percy Henry, The Foundations and the Future of International Law, Cambridge Universtiy Press, 1941. 


\title{
THE ROLE OF INTERNATIONAL ORGANIZATIONS IN INTERNATIONAL RELATIONS - THE EXAMPLE OF THE UNITED NATIONS
}

\begin{abstract}
In legal theory, there are numerous divisions between actors of international law, but a special significance of this issue is the division into actors with full and partial legal personality. This division is the most obvious in the adjudication of the International Court of Justice "Reparation for Injuries", which explicitly states that subjects of law in any legal system are not necessarily identical in nature and in the context of their rights. Thus, states are considered the only actors with full legal personality. This completeness is reflected in the fact that they have, or at least can have, all the rights and take on all obligations in the international legal system. On the other hand, other participants, such as international organizations or individuals, have only some elements entrusted to them by states. International organizations do not represent the original subjects of international law - they are exclusively states. Over time, international organizations have gained an increasing role, and their importance grows. However, one organization has strengthened this subjectivity - it is, of course, the United Nations. What makes the United Nations so special in relation to other international organizations, but also to other actors in international law?

Keywords: international organizations, international relations, full and partial legal personality, states.
\end{abstract}

